\title{
Pengaruh Layanan Google Terhadap Motivasi Belajar Untuk Mendukung Prestasi Belajar Siswa
}

\author{
Muhammad Haviz Irfani, Daniel Udjulawa \\ ${ }^{1}$ Sistem Informasi, STMIK GI MDP \\ haviz.irfani@mdp.ac.id \\ ${ }^{2}$ Teknik Informatika, STMIK GI MDP \\ daniel@mdp.ac.id
}

\begin{abstract}
Information technology in education sector affected on learning process held by senior high school in Palembang city. Some 77,43\% computer users (including students) who visit the google pages with the number of of 4,464,000,000 visitors everyday. Particularly students are very depend on search engine to to search of information or matter to complete a task school that relies heavily with the internet, thereby should be tested what factors affecting and could provide motivation to study and improve student learning achievements. The results of literature give you some of factors affect the motivation to study and student learning achievements that is a source of learning, intensity using, the quality of information. The methodology used namely AMOS (Analysis of Moment Structure), and path analysis, calculation the probability between endogenous, or endogenous and exogenous by the application of SEM (Structural Equation Model). The results of the study gained may be used as input for school management to make maximum use of google search engine in increased the motivation to study and student learning achievements.
\end{abstract}

Keyword: Student, Google Search Engine, Analysis of Moment Structure, Structural Equation Model, Path Analysis.

\begin{abstract}
Abstrak
Teknologi Informasi dalam dunia pendidikan sangat mempengaruhi proses belajar mengajar yang diselenggarakan oleh sekolah tingkat atas di kota Palembang. Sebanyak 77,43\% pengguna komputer (termasuk siswa) yang berkunjung ke laman Google dengan jumlah 4,464,000,000 pengunjung setiap harinya. Khususnya siswa sangat bergantung dengan mesin pencarian dalam mencari informasi ataupun materi untuk menyelesaikan tugas sekolah yang sangat bergantung dengan internet, sehingga perlu diuji faktor-faktor apa saja yang mempengaruhi dan dapat memberikan motivasi belajar serta meningkatkan prestasi belajar siswa. Hasil tinjauan literatur memberikan beberapa faktor yang mempengaruhi motivasi belajar dan prestasi belajar siswa yaitu Sumber Belajar, Intensitas Pengguna, Kualitas Informasi. Metode Penelitian yang digunakan yaitu AMOS (Analysis of Moment Structure), dan analisis Jalur; perhitungan probabilitas antar endogen, ataupun endogen dan eksogen dengan aplikasi SEM (Structural Equation Model). Hasil penelitian diperoleh dapat dijadikan masukan bagi pihak sekolah untuk memaksimalkan penggunaan search engine Google dalam meningkatkan motivasi belajar dan prestasi belajar siswa.
\end{abstract}

Kata kunci: Siswa, Mesin Pencarian Google, Analysis of Moment Structure, Structural Equation Model, Analisis Jalur 


\section{PENDAHULUAN}

Peraturan Pemerintah Nomor 19 Tahun 2005 tentang standar nasional pendidikan. Salah satu standar nasional yang dimaksudkan yaitu standar proses belajar.

Teknologi informasi seperti internet dengan peringkat pengguna internet di Indonesia mencapai 83,7 juta orang pada tahun 2014 (Gambar 1) pada dunia pendidikan pun sangat berpengaruh besar perubahan budaya belajar siswa dengan tidak terbatasnya ruang/ waktu belajar serta mempunyai akses informasi yang luas. Perlunya untuk mengetahui seberapa erat faktor-faktor yang mempengaruhi motivasi belajar siswa dan prestasi belajar siswa, agar dapat memberikan informasi bagi stakeholder yang terlibat maupun yang memiliki visi yang sama dalam dunia pendidikan.

Teknologi informasi Google didirikan oleh Larry Page dan Sergey Brin di Universitas Stanford.Adapun produk Google meliputi teknologi pencarian, komputasi web, perangkat lunak,dan periklanan. Teknologi Google Search merupakan google yang dikenal luas karena layanan pencariannya mudah digunakandan salah satu faktor terbesar dari kesuksesan Google Inc.
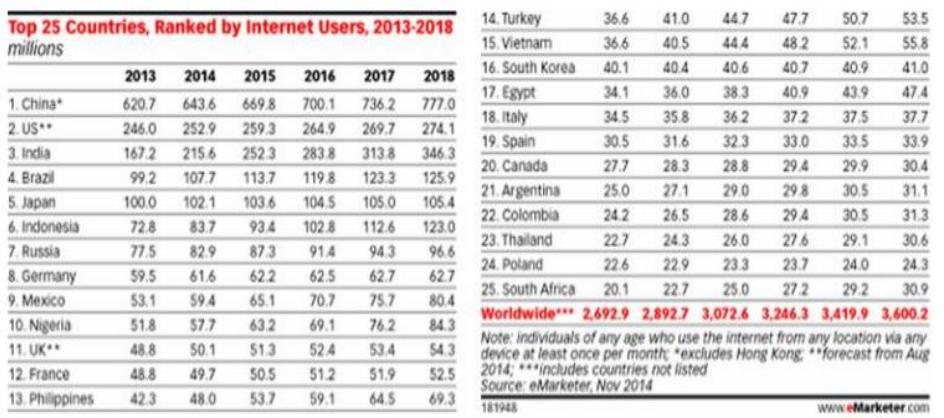

Sumber : Kompas.com Kategori Sorotan Media 2014

Gambar 1. Peringkat Pengguna Internet Indonesia Nomor Enam

\section{Keberadaan Mesin Pencarian Google.}

Pada April 2017 mengikuti net market share (http://www.smartinsights.com/searchengine-marketing/search-engine-statistics/), Google merupakan mesin pencari di web yang paling banyak digunakan dengan pangsa pasar sebesar 77,43\%, kemudian Baidu $(8,13 \%)$, Bing $(7,31 \%)$, dan Yahoo (5,6\%). Google juga memiliki miliaran halaman web untuk mencari informasi termasuk pencarian gambar, google news, google product search, google groups, google maps dan lain sebagainya melalui kata kuncinya maupun operator ${ }^{1}$. Dalam sebuah penelitian yang dilakukan oleh lembaga survey Chitika menyatakan bahwa Google digunakan hampir oleh 74 persen pengguna internet secara overall [10].

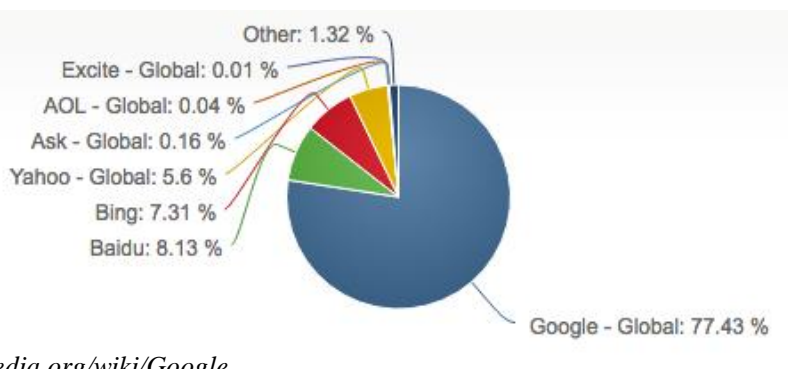

${ }^{1}$ http://id.wikipedia.org/wiki/Google

Gambar 2. Persentase Pengguna Internet pada Fitur Search Engine 
Penelitian ini memiliki responden sebanyak 254 data yang di survey dari 3 Sekolah Menengah Atas (SMA) swasta di kota Palembang memberikan persentase siswa laki-laki sebanyak $42,2 \%$ dan siswa perempuan sebanyak $57,8 \%$.

Berikut ini tabel tinjauan penelitian terdahulu (Tabel 1).

Tabel 1. Ringkasan Penelitian Sebelumnya [1][2][3]

[4][5][11][12]

\begin{tabular}{|c|c|c|c|}
\hline No & Nama Peneliti & Judul Penelitian & Faktor-faktor \\
\hline 1. & $\begin{array}{l}\text { Ahmad Sultoni } \\
\text { (2013) }\end{array}$ & 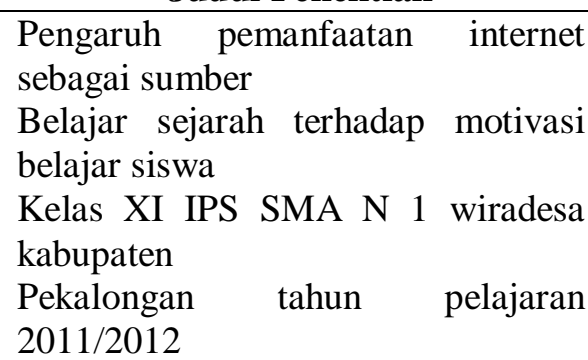 & $\begin{array}{l}\text { Sumber Belajar (Pemahaman, } \\
\text { Ketersediaan, Ketepatan } \\
\text { Fungsi, Intensitas User, Fitur } \\
\text { yang sering digunakan), dan } \\
\text { Motivasi Belajar. }\end{array}$ \\
\hline 2. & $\begin{array}{l}\text { Sushma Bagavadi } \\
\text { Ellore,Suman } \\
\text { Niranjan and } \\
\text { Ulysses J. Brown. } \\
(2014)\end{array}$ & $\begin{array}{l}\text { The Influence of Internet Usage on } \\
\text { Academic Performance and Face-to- } \\
\text { Face Communication }\end{array}$ & $\begin{array}{l}\text { Rancangan instruksional, } \\
\text { Kualitas informasi, Prestasi, } \\
\text { intensitas pengguna. }\end{array}$ \\
\hline 3. & $\begin{array}{l}\text { Anggoro D., L. } \\
\text { dan Sudji, M. } \\
\text { (2013) }\end{array}$ & $\begin{array}{l}\text { Pengaruh Pemanfaatan } \text { Internet, } \\
\text { Lingkungan, dan Motivasi Belajar } \\
\text { terhadap Prestasi Belajar Siswa } \\
\text { SMK }\end{array}$ & $\begin{array}{l}\text { Distribusi Pemanfaatan } \\
\text { Internet, Lingkungan, Motivasi } \\
\text { Belajar, dan Prestasi Belajar. }\end{array}$ \\
\hline 4. & $\begin{array}{l}\text { Risyad } \\
\text { Fauziansyah Budi } \\
\text { (2013) }\end{array}$ & $\begin{array}{l}\text { Pengaruh Kualitas Web Terhadap } \\
\text { Kepuasan Pengguna Google Shcolar } \\
\text { (Studi pada Mahasiswa Unair } \\
\text { Sebagai Penunjang Kegiatan } \\
\text { Akademis) }\end{array}$ & $\begin{array}{l}\text { Kualitas Informasi, Kualitas } \\
\text { Desain, Kualitas Pengguna, } \\
\text { Kepuasan Pengguna. }\end{array}$ \\
\hline 5. & $\begin{array}{l}\text { Betsy Sparrow, } \\
\text { Jenny Liu, Daniel } \\
\text { M. Wegner } \\
\text { (2011) }\end{array}$ & $\begin{array}{l}\text { Google Effects on Memory: } \\
\text { Cognitive Consequences of Having } \\
\text { Information at Our Fingertips }\end{array}$ & 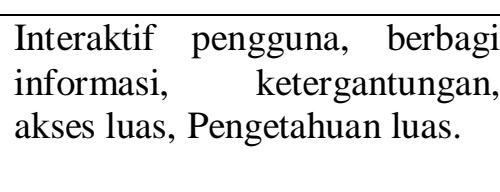 \\
\hline 6. & $\begin{array}{l}\text { Pram Satyo Aji, } \\
\text { Drs. Suparman } \\
\text { M.Pd. (2013) }\end{array}$ & $\begin{array}{l}\text { Pengaruh Media pembelajaran } \\
\text { menggunakan macromedia flash } 8 \\
\text { pokok bahasan internet pada mata } \\
\text { pelajaran TIK terhadap prestasi } \\
\text { belajar siswa kelas XI IPA SMA N } 6 \\
\text { Purworejo }\end{array}$ & $\begin{array}{l}\text { Efektif; } \\
\text { belajar. }\end{array}$ \\
\hline 7 & $\begin{array}{l}\text { Hutari Puji Astuti } \\
\text { (2011) }\end{array}$ & $\begin{array}{l}\text { Pengaruh antara Pemanfaatan } \\
\text { Sumber Belajar dan Motivasi } \\
\text { terhadap Prestasi Belajar Mata } \\
\text { Kuliah ASKEB II Mahasiswa } \\
\text { Program Studi D III Kebidanan } \\
\text { STIKES Kusuma Husada Surakarta }\end{array}$ & $\begin{array}{l}\text { Pemanfaatan Sumber Belajar } \\
\text { (kategori Intensitas tinggi- } \\
\text { sedang -rendah), Motivasi } \\
\text { Belajar (hasrat dan keinginan, } \\
\text { dorongan dan kebutuhan, } \\
\text { harapan dan cita-cita, } \\
\text { penghargaan, kegiatan yang } \\
\text { menarik, lingkungan belajar), } \\
\text { dan Prestasi Belajar (kategori } \\
\text { baik sekali, baik, cukup, } \\
\text { kurang, kurang sekali) }\end{array}$ \\
\hline
\end{tabular}


Dari Tabel 1 diperoleh beberapa faktor yang mempengaruhi motivasi belajar siswa yaitu Sumber Belajar, Intensitas Pengguna, Kualitas Informasi, kemudiandibuatlah model penelitian yang merujuk pada model penelitian analisis jalur seperti pada Gambar 3.

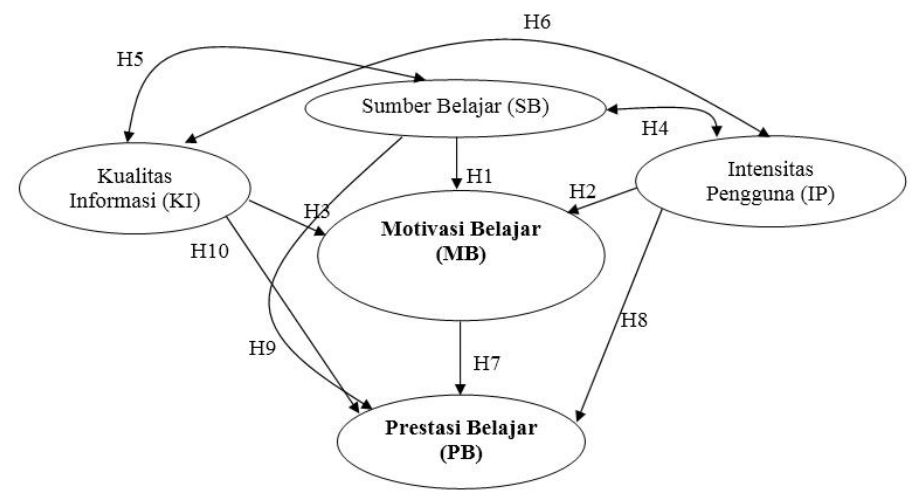

Gambar 3. Rancangan Model Penelitian Awal [6]

Berikut ini uraian hipotesis yang diperoleh dari Gambar 3 menjelaskan hubungan antar variabel (endogen dan eksogen).

Hipotesis 1: Hipotesis ini menguji hubungan langsung antara variabel SB dengan variabel MB. H0: SB tidak memiliki pengaruh langsung terhadap MB.

H1: SB memiliki pengaruh langsung terhadap MB.

Hipotesis 2: Hipotesis ini menguji hubungan langsung antara variabel IP dengan variabel MB. H0: IP tidak memiliki pengaruh langsung terhadap MB.

H1: IP memiliki pengaruh langsung terhadap MB.

Hipotesis 3: Hipotesis ini menguji hubungan langsung antara variabel KI dengan variabel MB.

H0: KI tidak memiliki pengaruh langsung terhadap MB.

H1: KI memiliki pengaruh langsung terhadap MB.

Hipotesis 4: Hipotesis ini menguji hubungan langsung antara variabel SB dengan variabel IP. H0: SB dan IP tidak saling mempengaruhi secara simultan

H1: SB dan IP saling mempengaruhi secara simultan.

Hipotesis 5: Hipotesis ini menguji hubungan langsung antara variabel KI dengan variabel SB.

H0: KI dan SB tidak saling mempengaruhi secara simultan.

H1: KI dan SB saling mempengaruhi secara simultan.

Hipotesis 6: Hipotesis ini menguji hubungan langsung antara variabel KI dengan variabel IP.

H0: KI dan IP tidak saling mempengaruhi secara simultan.

H1: KI dan IP saling mempengaruhi secara simultan.

Hipotesis 7: Hipotesis ini menguji hubungan langsung antara variabel MB dan PB.

H0: MB tidak memiliki pengaruh langsung terhadap PB.

H1: MB memiliki pengaruh langsung terhadap PB.

Hipotesis 8: Hipotesis ini menguji hubungan langsung antara variabel IP dan PB.

H0: IP tidak memiliki pengaruh langsung terhadap PB.

H1: IP memiliki pengaruh langsung terhadap PB.

Hipotesis 9: Hipotesis ini menguji hubungan langsung antara variabel SB dan PB.

H0: SB tidak memiliki pengaruh langsung terhadap PB.

H1: SB memiliki pengaruh langsung terhadap PB.

Hipotesis 10: Hipotesis ini menguji hubungan langsung antara variabel KI dan PB.

H0: KI tidak memiliki pengaruh langsung terhadap PB.

H1: KI memiliki pengaruh langsung terhadap PB. 


\section{TINJAUAN PUSTAKA}

\section{Beberapa Fitur Pencarian Google.}

Ada beberapa fitur khusus pada Google yang sering digunakan oleh pengguna antara lain ${ }^{\mathbf{1} 2}$ :

1. Pencarian Gambar (BETA); Google mempertimbangkan beberapa faktor ketika menentukan sebuah gambar relevan dengan permintaan pencarian pengguna

2. Terjemahan Halaman Web; Google memungkinkan orang berbahasa Inggris untuk dapat mengakses sejumlah halaman web non-Inggris.

3. Mencari dengan Kategori ; Google Web Directory memberikan informasi terstruktur, sangat berguna bagi pengguna yang memiliki gambaran umum tentang informasi.

Pencarian file PDF; Walaupun file PDF jumlahnya tidak sebanyak file HTML, format file PDF memuat informasi yang bermutu tinggi bahkan tidak tersedia di pencarian lainnya.

\section{Tabulasi Item Pengukuran dalam Penelitian.}

Tabel 2. Item Pengukuran Penelitian [1][2][3][4][5]

\begin{tabular}{|l|l|}
\hline \multicolumn{1}{|c|}{ Konstruk } & \multicolumn{1}{|c|}{ Indikator Pengukuran } \\
\hline Sumber Belajar (SB) & X11:Bahan pustaka siswa untuk menunjang \\
Ahmad Sultoni ,2013; Hutari Puji & proses belajar \\
Astuti (2011); Anggoro D., L. dan & X12:Ketepatan fungsi Google sebagai sumber belajar \\
Sudji, M.(2013) & X13: Pemahaman sikap siswa terhadap informasi \\
& X14:Ketersediaan informasi pada Google \\
\hline Intensitas Pengguna (IP) & X21:Praktis, ekonomis, dan sederhana \\
Risyad Fauziansyah Budi (2013); & X22:Fasilitas Google yang sering digunakan \\
Pram Satyo Aji, Drs. Suparman M.Pd. & X23:Kecepatan dan kemudahan akses Google \\
(2013) & X24:Pemanfaatan jangka panjang \\
\hline Kualitas Informasi (KI) & X31:Informasi yang terbarui \\
Ahmad Sultoni,2013; & X32:Referensi/pustaka yang menarik \\
Risyad Fauziansyah Budi ,2013; & X33:Penilaian hasil usaha \\
Hutari Puji Astuti,2011 & Y11:Dorongan mental siswa \\
\hline $\begin{array}{l}\text { Motivasi Belajar (MB) } \\
\text { Ahmad Sultoni,2013;Anggoro D., L. } \\
\text { dan Sudji, M.,2013;Hutari Puji Astuti, }\end{array}$ & Y12:Kesungguhan dalam belajar \\
2011. & Y13:Kecerdasan memanfaatkan waktu \\
\hline Prestasi Belajar (PB) & Y21:Kecerdasan emosi, minat, bakat dan kemauan \\
Anggoro D., L. dan Sudji, M.,2013; & Y22:Strategi yang digunakan \\
Risyad Fauziansyah Budi,2013; & Y23:Hasil belajar siswa \\
Pram Satyo Aji, Drs. Suparman & \\
M.Pd.,2013;Hutari Puji Astuti,2011. & \\
\hline
\end{tabular}

Tabel 2 merupakan uraian item pengukuran untuk setiap variabel manifestasi masingmasing eksogen yang disusun dari pembelajaran literatur pada Tabel 1.

\section{Terminologi SEM (Structural Equation Modelling).}

\section{A. Variabel Manifest (Observed Variable) dan Variabel Laten}

Variabel manifest yaitu variabel yang dapat langsung diukur, sedangkan variabel laten merupakan variabel yang tidak dapat diukur secara langsung melainkan dengan beberapa variabel manifest. 


\section{B. Measurement Model dan Structural Model}

Measurement model adalah bagian dari model SEM yang menggambarkan hubungan antara variabel laten dengan indikator-indikatornya. Selain itu, Structural model adalah model yang menggambarkan hubungan antar variabel-variabel laten atau antar variabel eksogen dengan variabel laten.

\section{Error pada Pengukuran}

Error pada structural model disebut dengan residual error yang merefleksikan varians yang tidak dapat dijelaskan dalam variabel endogen karena semua faktor yang tidak dapat diukur.

\section{Analisis SEM}

Secara umum, ada lima tahap dalam prosedur SEM [8] yaitu:

(1) Spesifikasi model: membuat sebuah model (bentuk equation atau persamaan matematis; bentuk diagram).

(2) Identifikasi model: apakah dapat dianalisis lebih lanjut (menentukan degree of freedom).

(3) Estimasi model: menentukan maximum likelihood (ML), generalized least square (GLS), instrument variabel (IS), two stage least square (2SLS), unweight least square (ULS), generally weight least square (WLS), dan diagonally weight least square (DWLS).

(4) Uji kecocokan model: ukuran uji kecocokan seperti absolute fit measures, incremental/ relative fit measures, dan parsimony/ adjusted fit measures.

(5) Respesifikasi model: Apabila hipotesis model belum fit maka peneliti dapat respesifikasi model untuk mencapai nilai fit yang baik.

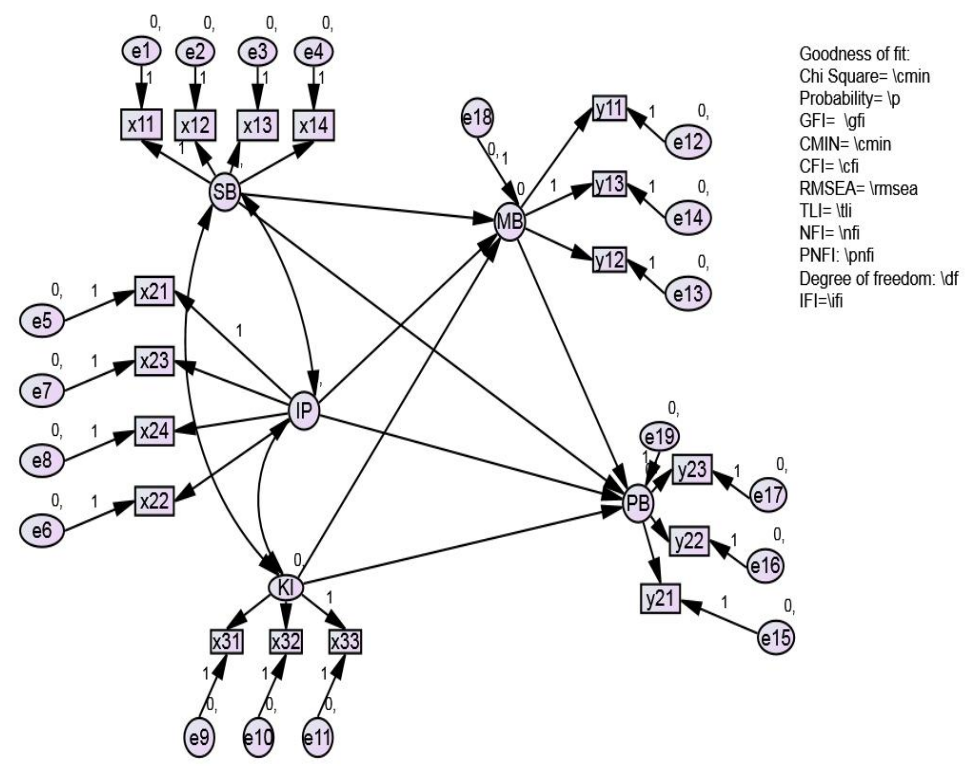

Gambar 4. Model Struktural Manifestasi dan Laten.

Dari Gambar 4 terlihat variabel laten eksogen (tidak dapat diukur secara langsung) yaitu kualitas informasi (KI), sumber belajar (SB), dan intensitas pengguna (IP). Sedangkan variabel laten endogen yaitu motivasi belajar dan prestasi belajar. Hubungan korelasi $\mathrm{KI} \leftrightarrow \mathrm{SB}, \mathrm{KI} \leftrightarrow \mathrm{IP}$, dan SB $\leftrightarrow$ IP. Sementara hubungan regresi ( $\gamma \mathrm{i}$ ) dapat terjadi pada $\mathrm{KI} \rightarrow \mathrm{MB}, \mathrm{SB} \rightarrow \mathrm{MB}, \mathrm{IP} \rightarrow \mathrm{MB}$, dan regresi $(\gamma \mathrm{i}+1) \quad \mathrm{MB} \rightarrow \mathrm{PB}$. Variabel manifestasi (untuk variabel eksogen) yaitu $\mathrm{X} 11, \mathrm{X} 12, \mathrm{X} 13, \mathrm{X} 14$ membentuk konstruk laten SB; X21,X22,X23, X24 membentuk konstruk laten IP; X31,X32,X33 membentuk konstruk laten KI; Y11,Y12,Y13 membentuk konstruk laten MB; dan Y21,Y22,Y23 membentuk konstruk laten PB. Kesalahan structural yaitu e18 dan e19, selain itu juga setiap variabel manifestasi mempunyai error (kesalahan). Faktor 
pengukuran model yaitu nilai yang menghubungkan variabel laten dengan setiap manifesnya (secara multiple measure) paling banyak satu yang mewakili dan bernilai 1 , notasinya $\lambda \mathrm{ij}$ (SB dengan X11 adalah $\lambda 11$ dan seterusnya) Kesalahan pengukuran terdapat pada variabel manifestasi untuk masing-masing latennya.

Berikut ini model pengukuran untuk setiap variabel manifestasi dalam Gambar 4 [7][8]

$\mathrm{X} 11=\lambda 11 . \mathrm{SB}+\mathrm{e} 1$

$\mathrm{X} 12=\lambda 12 . \mathrm{SB}+\mathrm{e} 2$

$\mathrm{X} 13=\lambda 13 . \mathrm{SB}+\mathrm{e} 3$

$\mathrm{X} 14=\lambda 14 . \mathrm{SB}+\mathrm{e} 4$

$\mathrm{X} 21=\lambda 21 . \mathrm{IP}+\mathrm{e} 5$

$\mathrm{X} 22=\lambda 22 . \mathrm{IP}+\mathrm{e} 6$

$\mathrm{X} 23=\lambda 23 . \mathrm{IP}+\mathrm{e} 7$

$\mathrm{X} 24=\lambda 24 . \mathrm{IP}+\mathrm{e} 8$

$\mathrm{X} 31=\lambda 31 . \mathrm{KI}+\mathrm{e} 11$

$\mathrm{X} 32=\lambda 32 . \mathrm{KI}+\mathrm{e} 10$

$\mathrm{X} 33=\lambda 33 . \mathrm{KI}+\mathrm{e} 9$

$\mathrm{Y} 11=\lambda 41 . \mathrm{MB}+\mathrm{e} 14$

$\mathrm{Y} 12=\lambda 42 . \mathrm{MB}+\mathrm{e} 13$

$\mathrm{Y} 13=\lambda 43 . \mathrm{MB}+\mathrm{e} 12$

$\mathrm{Y} 21=\lambda 51 . \mathrm{PB}+\mathrm{e} 17$

$\mathrm{Y} 22=\lambda 52 . \mathrm{PB}+\mathrm{e} 16$

$\mathrm{Y} 23=\lambda 53 . \mathrm{PB}+\mathrm{e} 15$

$\mathrm{MB}=\gamma 1 . \mathrm{SB}+\gamma 2 . \mathrm{IP}+\gamma 3 . \mathrm{KI}+\mathrm{e} 18$

$\mathrm{PB}=\beta 1 . \mathrm{MB}+\mathrm{e} 19$

\section{METODE PENELITIAN}

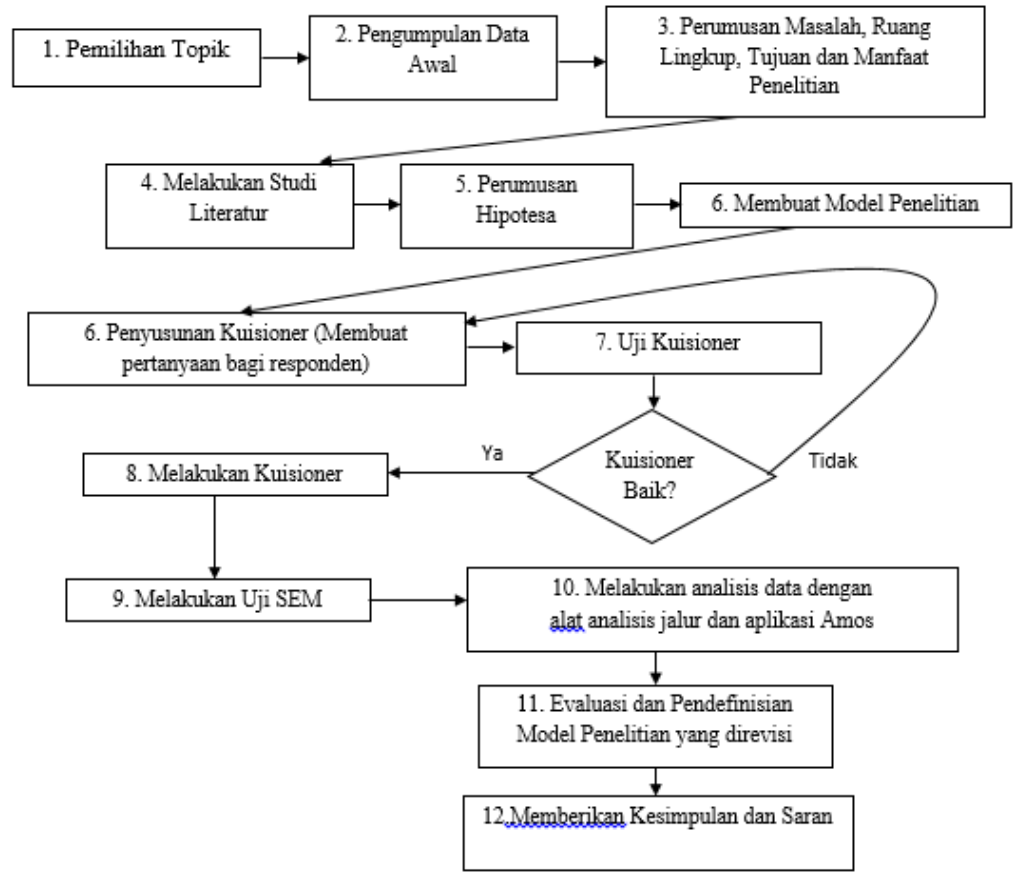

Gambar 5. Skema Metodologi Penelitian 
Gambar 5 memperlihatkan metodologi penelitian yang dilakukan dengan memberikan tahapan secara sistematis dan logis.

\section{HASIL DAN PEMBAHASAN}

Hasil luaran aplikasi AMOS setelah dilakukan running pertama kali pada model struktural (Gambar 5).

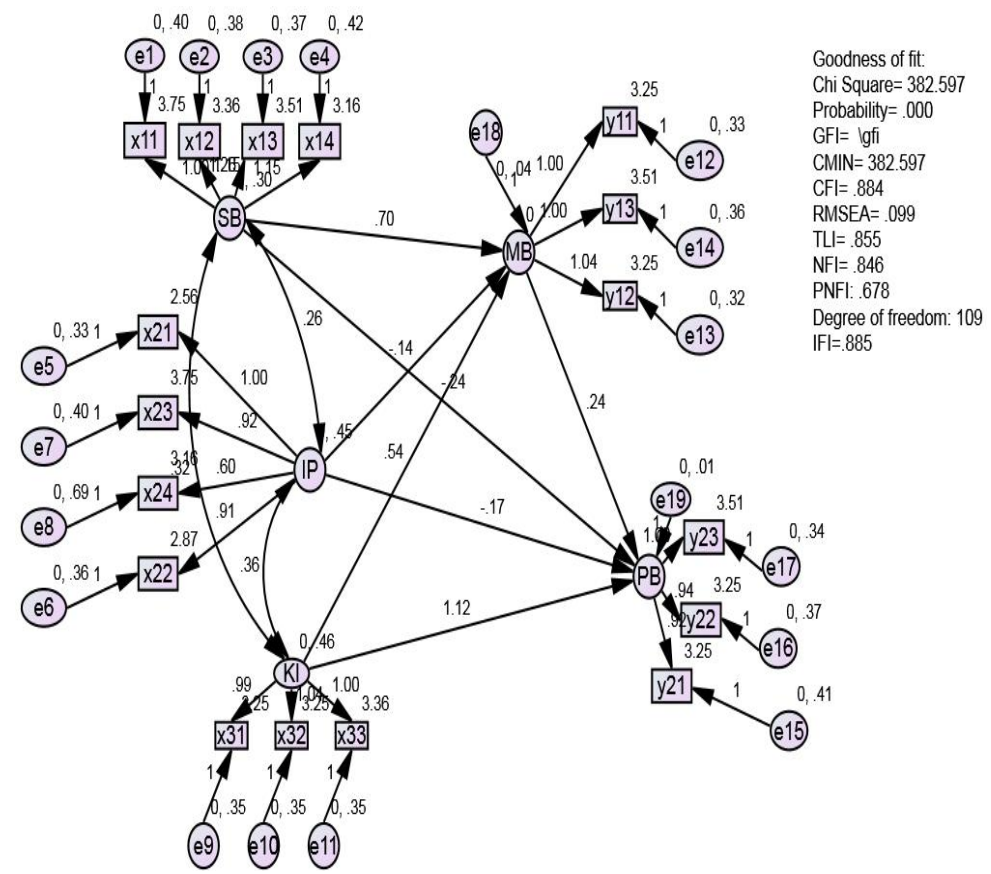

Gambar 6. Model Struktural Variabel Konstruk dan Manivestasi Sebelum Modifikasi [7][8][9]

\section{Computation of degrees of freedom (Default model)}

Number of distinct sample moments: $\quad 170$

Number of distinct parameters to be estimated: 61

Degrees of freedom (90 - 43):

109
Result (Default model)
Minimum was achieved
Chi-square $=382.597$
Degrees of freedom $=109$
Probability level $=.000$

Tabel 3. Menilai Goodness of Fit Indeks dari Model Sebelum Modifikasi [8]

\begin{tabular}{|c|c|c|c|}
\hline $\begin{array}{c}\text { Goodness of } \\
\text { Fit Indeks }\end{array}$ & $\begin{array}{c}\text { Cut of } \\
\text { Value }\end{array}$ & $\begin{array}{c}\text { Hasil } \\
\text { Analisis }\end{array}$ & $\begin{array}{c}\text { Evaluasi } \\
\text { Model }\end{array}$ \\
\hline & $\leq 137.701$, & & \\
Chi Square & $\begin{array}{c}\text { Square untuk df } \\
=109 ; \text { Taraf } \\
\text { Sig 5\% } \\
\end{array}$ & 382.597 & Tidak Baik \\
& $=137.701$ & & \\
\hline
\end{tabular}




\begin{tabular}{|c|c|c|c|}
\hline Probability & $>0.05$ & 0.000 & Tidak Baik \\
\hline GFI & $>0.90$ & $\begin{array}{c}\text { Tidak } \\
\text { Terbaca }\end{array}$ & Tidak Baik \\
\hline IFI & $>0.90$ & 0.885 & Marginal \\
\hline TLI & $>0.90$ & 0.855 & Marginal \\
\hline CFI & $>0.90$ & 0.884 & Marginal \\
\hline NFI & $>0.90$ & 0.846 & Marginal \\
\hline RMSEA & $<0.08$ & 0.099 & Marginal \\
\hline
\end{tabular}

Dari hasil analisis model (Tabel 3) terlihat bahwa Model structural tersebut dengan data penelitian menunjukkan hasil model yang kurang fit dan kurang goods. Analisis lanjutan yang dapat dilakukan yaitu dengan menghilangkan mahalanobis square.

Tabel 4. Nilai Mahalanobis d-square yang Akan Direvisi sampai < 30.000 [8][9]

Observations Farthest from The Centroid

(Mahalanobis Distance) (Group Number 1)

\begin{tabular}{|c|c|c|c|}
\hline Observation number & Mahalangbis d-squared & p1 & p2 \\
\hline 86 & 748 & .000 & .020 \\
\hline 214 & 48.273 & .000 & .000 \\
\hline 64 & 46.640 & .000 & .000 \\
\hline 192 & 46.640 & .000 & .000 \\
\hline 45 & 38.270 & .002 & .000 \\
\hline 173 & 38.270 & .002 & .000 \\
\hline 78 & 34.018 & .008 & .006 \\
\hline 206 & 34.018 & .008 & .002 \\
\hline 57 & 33.838 & .009 & .001 \\
\hline 185 & 33.838 & .009 & .000 \\
\hline 67 & 33.494 & .010 & .000 \\
\hline 195 & 33.494 & .010 & .000 \\
\hline 55 & 33.007 & .011 & .000 \\
\hline 183 & 33.007 & .011 & .000 \\
\hline 41 & & .037 & .001 \\
\hline $\begin{array}{c}::: \\
\text { Dan seterusnya }\end{array}$ & Dan seterusnya & & \\
\hline
\end{tabular}

Hilangkan mahalanobis d-square > 30.00, hasil yang diperoleh sebagai berikut: 
Tabel 5. Nilai Mahalanobis d-square Setelah Direvisi [8]

Observations Farthest from The Centroid

(Mahalanobis Distance) (Group Number 1)

\begin{tabular}{|c|ccc|}
\hline Observation number & Mahalanobis d-squared & $\mathrm{p} 1$ & $\mathrm{p} 2$ \\
\hline 34 & 29.835 & .028 & .997 \\
139 & 29.835 & .028 & .980 \\
47 & 29.524 & .030 & .952 \\
152 & 29.524 & .030 & .877 \\
39 & 28.968 & .035 & .858 \\
144 & 28.968 & .035 & .742 \\
36 & 28.716 & .037 & .668 \\
141 & 28.716 & .037 & .524 \\
54 & 28.624 & .038 & .409 \\
159 & 28.624 & .038 & .282 \\
Dan seterusnya & Dan seterusnya & \\
\hline
\end{tabular}

Tabel 4 dan Tabel 5 adalah luaran sebelum dan sesudah dilakukannya proses penghilangan mahalanobis, data yang dihapus dilakukan sekaligus untuk satuan running yang dilakukan dengan memperhatikan nomor barisnya.

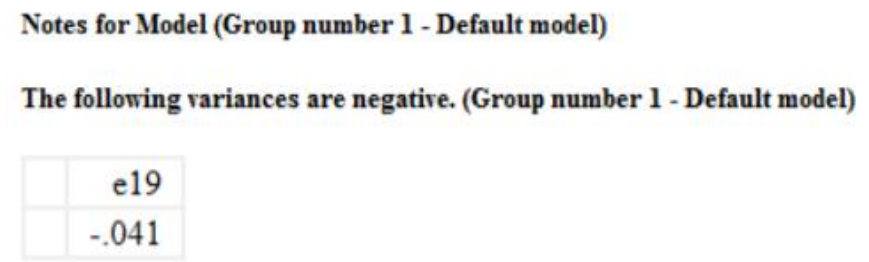

\begin{tabular}{|l|rrrrrr}
\hline Variable & $\min$ & $\max$ & skew & c.r. & kurtos & c.r. \\
\hline x22 & 1.000 & 3.618 & -.653 & -3.860 & -.75 & -2.220 \\
y11 & 1.000 & 4.075 & -.604 & -3.576 & -.667 & -1.974 \\
x24 & 1.000 & 4.313 & -.287 & -1.699 & -.792 & -2.342 \\
x13 & 1.631 & 4.727 & -.119 & -.705 & -.775 & -2.293 \\
y23 & 1.000 & 4.676 & -.142 & -.838 & -.787 & -2.329 \\
y22 & 1.000 & 4.293 & -.352 & -2.085 & -.788 & -2.330 \\
y21 & 1.000 & 4.385 & -.242 & -1.433 & -.723 & -2.139 \\
y12 & 1.000 & 4.193 & -.348 & -2.058 & -.699 & -2.069 \\
y13 & 1.000 & 4.596 & -.285 & -1.686 & -.281 & -.832 \\
x31 & 1.000 & 4.166 & -.541 & -3.200 & -.59 & -1.765 \\
x32 & 1.000 & 4.487 & -.315 & -1.863 & -.196 & -.581 \\
x33 & 1.000 & 4.331 & -.498 & -2.945 & -.450 & -1.330 \\
x23 & 1.000 & 4.583 & -.612 & -3.619 & -.605 & -1.791 \\
x21 & 1.000 & 3.421 & -.486 & -2.875 & -.988 & -2.921 \\
x14 & 1.000 & 4.133 & -.386 & -2.281 & -.758 & -2.243 \\
x12 & 1.000 & 4.223 & -.597 & -3.531 & -.480 & -1.420 \\
x11 & 1.000 & 4.389 & -.935 & -5.532 & -.172 & -.508 \\
Multivariate & & & & & 19.572 & 5.580
\end{tabular}

Gambar 7. Penilaian Data Berdistribusi Normal.[8][9] 
Setelah penghilangan mahalanobis, diperoleh Gambar 8 yang menunjukkan nilai $\mathrm{cr}<2.58$ bahwa data berdistribusi normal secara individu. Setelah data normal dilakukan modifikasi model dari tabel pada modification indices.

Tabel 6. Penambahan Korelasi Antar Variabel Error, Maupun Variabel Error dan Laten.[8][9]

Covariances: (Group number 1 - Default model)

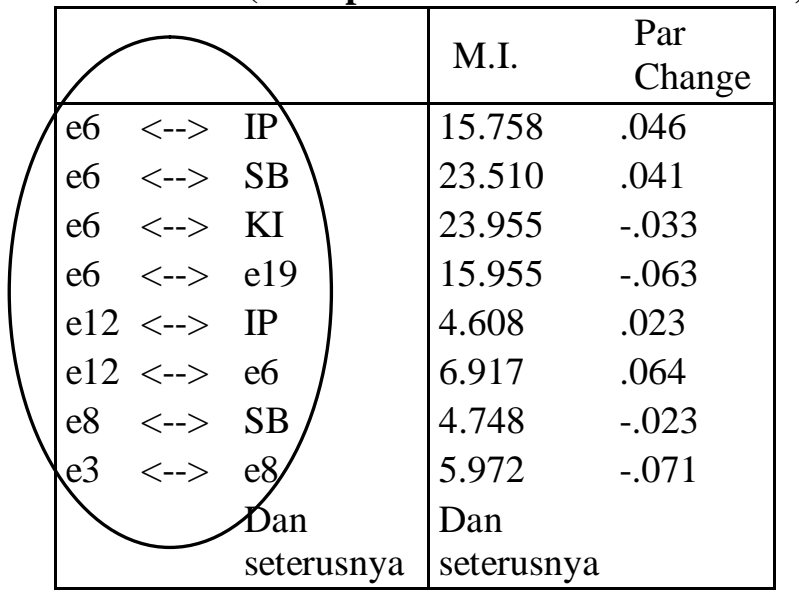

Instruksi pada Tabel 6 untuk modifikasi model struktural sebelumnya dilakukan secara bertahap dengan cara membuat korelasi model misalnya e6 $\leftrightarrow$ IP lalu model dirunning kembali, lakukan berulang kali sampai tabel covarians kosong. Hasil korelasi dan regresi antar variabel konstruk dan manifestasi memberikan nilai akhir sebagai berikut:

\section{Result (Default model)}

Minimum was achieved

Chi-square $=72.049$

Degrees of freedom $=63$

Probability level $=.203$

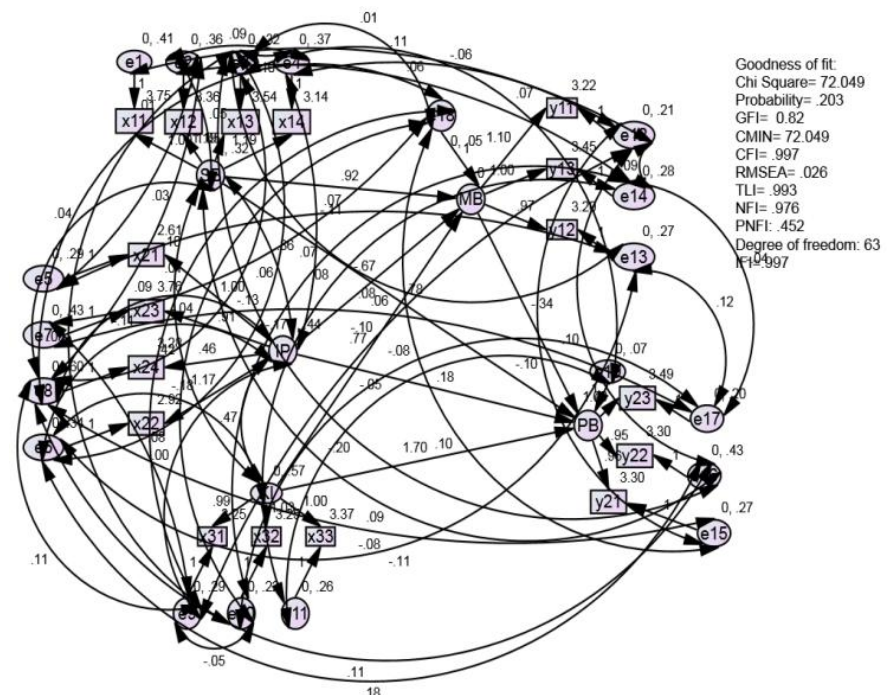

Gambar 8. Model Struktural Variabel Konstruk dan Manivestasi Setelah di Modifikasi.[8] 
Gambar 9 memperlihatkan model akhir yang telah dimodifikasi, Nilai $\mathrm{df}=63$ adalah positif artinya pengujian model dapat dilakukan,nilai probabilitas $0.203>0.05$ artinya secara keseluruhan model diatas telah fit dengan data sampel.

Tabel 7 menunjukkan kesimpulan dari output aplikasi AMOS untuk model fit.

Tabel 7. Menilai Goodness of Fit Indeks dari Model Setelah Modifikasi.[8][9]

\begin{tabular}{|l|c|c|c|}
\hline $\begin{array}{c}\text { Goodness of } \\
\text { Fit Indeks }\end{array}$ & $\begin{array}{c}\text { Cut of } \\
\text { Value }\end{array}$ & $\begin{array}{c}\text { Hasil } \\
\text { Analisis }\end{array}$ & $\begin{array}{c}\text { Evaluasi } \\
\text { Model }\end{array}$ \\
\hline Chi Square & $\begin{array}{c}\text { Dimana Chi } \\
\text { Square untuk } \\
\text { df }=63 ; \text { Taraf Sig } \\
5 \%=72.0699\end{array}$ & $\begin{array}{c}72.049< \\
72.0699\end{array}$ & Baik \\
\hline Probability & $>0.05$ & 0.203 & Baik \\
\hline GFI & $>0.90$ & 0.82 & Baik \\
\hline IFI & $>0.90$ & 0.997 & Baik \\
\hline TLI & $>0.90$ & 0.993 & Baik \\
\hline CFI & $>0.90$ & 0.997 & Baik \\
\hline NFI & $>0.90$ & 0.976 & Baik \\
\hline RMSEA & $<0.08$ & 0.026 & Baik \\
\hline
\end{tabular}

Absolut Fit Measure (Uji Kecocokan Absolut) yaitu Chi Square, GFI, dan RMSEA semuanya memberikan hasil Baik dan dapat disimpulkan bahwa model layak digunakan karena valid. Uji Kecocokan Inkremental TLI, NFI, CFI, dan IFI semuanya juga memberikan hasil Baik.

Pada Tabel 8 terlihat keluaran tabel regresi dan regresi standar memperlihatkan nilai $\mathrm{P}=$ $* * *$ yaitu probabilitas $<0.05$ sehingga faktor loading memiliki hubungan terhadap laten masingmasing, dan juga semua faktor loading menunjukkan nilai di atas 0.5 (Kolom Estimate) dan dapat menjelaskan konstruk yang ada.

Tabel 8. Menilai Hubungan Antara Faktor Loading dan Laten Eksogen.[8][9]

Regression Weights:

(Group number 1 - Default model)

\begin{tabular}{|ccc|cccc|}
\hline & & & Estimate & S.E. & C.R. & P \\
\hline x11 & $<---$ & SB & 1.000 & & & \\
x12 & $<---$ & SB & 1.054 & .103 & 10.198 & $* * *$ \\
x14 & $<---$ & SB & 1.190 & .114 & 10.453 & $* * *$ \\
x21 & $<---$ & IP & 1.000 & & & \\
x23 & $<---$ & IP & .907 & .085 & 10.680 & $* * *$ \\
x33 & $<---$ & KI & 1.000 & & & \\
x32 & $<---$ & KI & 1.026 & .068 & 15.129 & $* * *$ \\
x31 & $<---$ & KI & .993 & .071 & 13.990 & $* * *$ \\
y13 & $<---$ & MB & 1.000 & & & \\
y12 & $<---$ & MB & .969 & .067 & 14.495 & $* * *$ \\
\hline
\end{tabular}




\begin{tabular}{|ccc|cccc|}
\hline & & & Estimate & S.E. & C.R. & P \\
\hline y21 & $<---$ & PB & .963 & .061 & 15.690 & $* * *$ \\
y22 & $<---$ & PB & .953 & .074 & 12.890 & $* * *$ \\
y23 & $<---$ & PB & 1.000 & & & \\
x13 & $<---$ & SB & 1.190 & .110 & 10.804 & $* * *$ \\
x24 & $<---$ & IP & .460 & .094 & 4.923 & $* * *$ \\
y11 & $<---$ & MB & 1.097 & .084 & 13.065 & $* * *$ \\
x22 & $<---$ & IP & 1.170 & .108 & 10.882 & $* * *$ \\
\hline
\end{tabular}

Standardized Regression Weigh
(Group number 1 - Default mod
\begin{tabular}{|ccc|c|}
\hline & & Estimate \\
\hline x11 <--- & SB & .663 \\
x12 <--- & SB & .657 \\
x14 <--- & SB & .738 \\
x21 <--- & IP & .776 \\
x23 <--- & IP & .677 \\
x33 <--- & KI & .830 \\
x32 <--- & KI & .856 \\
x31 <--- & KI & .814 \\
y13 <--- & MB & .810 \\
y12 <--- & MB & .804 \\
y21 <--- & PB & .861 \\
y22 <--- & PB & .837 \\
y23 <--- & PB & .871 \\
x13 <--- & SB & .763 \\
x24 <--- & IP & .346 \\
y11 <--- & MB & .868 \\
x22 <--- & IP & .941 \\
\hline
\end{tabular}

Tabel 9. Menilai Hubungan Antar Laten Eksogen. [8][9]

Correlations: (Group number 1 - Default model)

\begin{tabular}{|c|c|}
\hline & Estimate \\
\hline KI $<-->$ SB & .988 \\
\hline SB $\langle-->\quad$ IP & .949 \\
\hline KI $<-->\quad$ IP & .935 \\
\hline
\end{tabular}

Tabel 10. Menilai Hubungan Antara Laten Eksogen dan Laten Endogen. [8][9]

Regression Weights:

(Group number 1 - Default model)

\begin{tabular}{|ccc|cccc|}
\hline & & & Estimate & S.E. & C.R. & P \\
\hline MB & $<---$ & IP & -.673 & .204 & -3.305 & $* * *$ \\
MB & $<---$ & SB & .924 & .192 & 4.820 & $* * *$ \\
MB & $<---$ & KI & .766 & .165 & 4.651 & $* * *$ \\
PB & $<---$ & MB & -.341 & .183 & -1.866 & .062 \\
PB & $<---$ & SB & -.775 & .313 & -2.480 & .013 \\
PB & $<---$ & KI & 1.702 & .235 & 7.237 & $* * *$ \\
\hline
\end{tabular}




\begin{tabular}{|ccc|cccc|}
\hline & & & Estimate & S.E. & C.R. & P \\
\hline PB & $<---$ & IP & .184 & .214 & .859 & .390 \\
\hline
\end{tabular}

Tabel 9 menunjukkan korelasi antar laten eksogen KI dan SB, SB dan IP, KI dan IP sangat erat. Selain itu Tabel 10 memperlihatkan juga hubungan motivasi belajar dipengaruhi sangat erat oleh Intensitas Pengguna, Sumber Belajar, dan Kualitas Informasi. Prestasi Belajar tidak dipengaruhi oleh Motivasi Belajar karena $\mathrm{p}=0.062>0.05$ sehingga Ho diterima pada hipotesa H7. Prestasi Belajar dipengaruhi sangat kuat oleh Kualitas Informasi $(\mathrm{P}=* * *)$ dan Sumber Belajar $(\mathrm{p}=0.013<0.05)$ yang pengaruh kuat. Tetapi Prestasi Belajar tidak dipengaruhi oleh Intensitas Pengguna karena mempunyai angka $\mathrm{P}=0.39<0.05$.

\section{KESIMPULAN}

Kesimpulan yang dapat ditarik setelah analisis SEM untuk persepsi siswa sekolah menengah atas yang menggunakan search engine Google yaitu:

1. Korelasiterjadi sangat kuat sebesar $98.8 \%$ antara Kualitas Informasi dan Sumber Belajar, persentase $94.9 \%$ korelasi kuat antara Sumber Belajar dan Intensitas Pengguna, dan persentase 93.5\% korelasi kuat antara Kualitas Informasi dan Intensitas Pengguna.

2. Untuk Prestasi Belajar tidak dipengaruhi Motivasi Belajar, dan Intensitas Pengguna.

3. Prestasi Belajar signifikan dipengaruhi oleh Sumber Belajar (hubungan sangat kuat $\mathrm{P}=* * *$ ) dan Kualitas Informasi (hubungan sangat kuat $\mathrm{p}=0.013<0.05$ ).

\section{DAFTAR PUSTAKA}

[1] Sultoni, A., 2013, Pengaruh Pemanfaatan Internet Sebagai Sumber Belajar Sejarah Terhadap Motivasi Belajar Siswa Kelas XI IPS SMA N 1 Wiradesa Kabupaten Pekalongan Tahun Pelajaran 2011/2012, Universitas Negeri Semarang, Indonesia.

[2] Anggoro D., L. dan Sudji, M., 2013, Pengaruh Pemanfaatan Internet, Lingkungan, dan Motivasi Belajar Terhadap Prestasi Belajar Siswa SMK, Jurnal Pendidikan Vokasi, Vol. 3, Nomor 3, 293-305, Universitas Negeri Yogyakarta, Indonesia.

[3] Fauziansyah Budi, R., 2013, Pengaruh Kualitas Web Terhadap Kepuasan Pengguna Google Shcolar (Studi pada Mahasiswa Unair Sebagai Penunjang Kegiatan Akademis), Media Libri-Net.Vol.2-No.1 terbit 1-2013, Indonesia.

[4] Satyo Aji,P. dan Suparman M.Pd., Drs., 2013, Pengaruh Media Pembelajaran Menggunakan Macromedia Flash 8 Pokok Bahasan Internet pada Mata Pelajaran TIK Terhadap Prestasi Belajar Siswa Kelas XI IPA SMA N 6 Purworejo, Jurnal Pendidikan Teknik Informatika Edisi 1 Tahun ke 2013, Kampus Karang Malang, Yogyakarta, 55281, Indonesia.

[5] Puji Astuti,H., 2011, Pengaruh Antara Pemanfaatan Sumber Belajar dan Motivasi Terhadap Prestasi Belajar Mata Kuliah ASKEB II Mahasiswa Program Studi D III Kebidanan STIKES Kusuma Husada Surakarta, Program Pasca Sarjana Universitas Sebelas Maret Surakarta, Indonesia.

[6] Nidjo Sandjojo, 2011, Metode Analisis Jalur (Path Analysis) dan Aplikasinya, ISBN 9794169463Pustaka Sinar Harapan, Jakarta. 
[7] Yamin, S., dan Kurniawan, H., 2009, Structural Equation Modeling: Belajar Lebih Mudah Teknik Analisis Data Kuisioner dengan Lisrel-PLS, Salemba Infotek, Jakarta.

[8] Ghozali Imam, Dr, Prof., 2015, Konsep dan Aplikasi dengan Program Amos 22.0, Badan Penerbit Universitas Diponegoro, Semarang.

[9] Santoso, S., 2012, Analisis SEM Menggunakan AMOS, Elex Media Komputindo, Jakarta.

[10] Baihaki Imam, 2012, Google Masih Jadi Search Engine Terpopuler, Digunakan 74 persen Pengguna Internet, BTekno, https://www.beritateknologi.com/google-masih-jadisearch-engine-terpopuler-digunakan-74-persen-pengguna-internet/

[11] Sushma Bagavadi Ellore, Suman Niranjan and Ulysses J. Brown., 2014, The Influence of Internet Usage on Academic Performance and Face-to-Face Communication, Journal of Psychology and Behavioral Science, Published by American Research Institute for Policy Development.

[12] Betsy Sparrow, Jenny Liu, Daniel M. Wegner, 2011, Google Effects on Memory: Cognitive Consequences of Having Information at Our Fingertips, ISSN 0036-8075; online ISSN 1095-9203, VOL. 333, SCIENCE, www.sciencemag.org. 